\title{
Does the Christian church have any guidance to offer in solving the global problems we are faced with today?
}

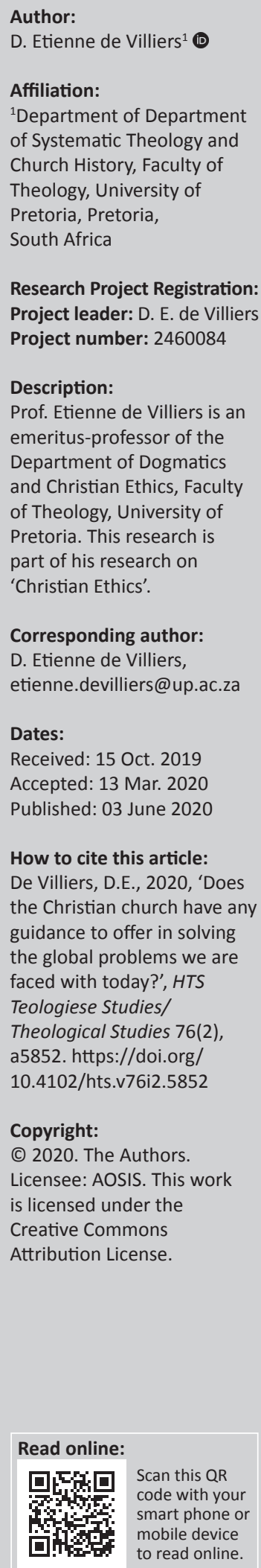

In his book, 21 Lessons for the 21st century, the historian Yuval Noah Harari devoted a chapter to the question of whether traditional religions could provide any guidance in solving the momentous global problems confronting us today. He drew the rather negative conclusion that they do not have any constructive contribution to make in solving these problems. This article made an original contribution to scholarly research by, from the perspective of Christian Ethics, subjecting this recently expressed view of Harari to critical scrutiny and by exploring the guidance the Christian church could offer in solving global problems we are faced with today, such as nuclear war, ecological collapse and technological disruption. These research objectives were realised by addressing four questions: (1) does the church have a responsibility to provide guidance in this regard? (2) What is the nature of the guidance the church ought to provide? (3) What are the factors hindering the church in providing such guidance? (4) Which conditions need to be fulfilled for the church to provide meaningful guidance? The answers provided to these questions were substantiated by drawing on the findings of published Christian ethical and social scientific research. The conclusion drawn from the article is that the church could today provide meaningful moral guidance in solving global problems. It should then, however, depart from an unbiased understanding of the message of the Bible and effectively deal with certain hindrances preventing it from providing adequate moral guidance.

Keywords: Church; Global problems; Christian ethics; Moral guidance; Responsibility of church.

\section{Introduction}

In his latest book, 21 Lessons for the 21st century, historian Yuval Noah Harari has devoted an entire chapter to address the question whether traditional religions can provide guidance in solving the momentous global problems confronting us today - problems such as nuclear war, ecological collapse and technological disruption. He draws a rather negative conclusion: 'when it comes to solving, rather than stoking the global problems of the twenty-first century, they don't seem to offer much' (Harari 2018:138). The first reason he provides for his conclusion is that traditional religions are largely irrelevant when it comes to the all-important technical and policy problems involved. They just do not have the expertise to provide technical and policy solutions (Harari 2018:128-133). The second reason is that the relevance they do have with regard to identity problems specifically causes them to obstruct rather than contribute to the solution of the global problems. As institutions with expertise in building strong mass identities, they today allow themselves to be used by governments to preserve unique national identities. As handmaids of modern nationalism, they make it even harder to transcend national differences and find a global solution to the threats of nuclear war, ecological collapse and technological disruption (Harari 2018:137-138).

In this article, I critically respond to Harari's view, from a Christian ethical perspective, by addressing four questions specifically with regard to the guidance that the Christian church could provide in solving global threats. These questions are: (1) does the church have a responsibility to provide guidance in this regard? (2) What is the nature of the guidance the church ought to provide? (3) What are the factors hindering the church in providing such guidance? (4) Which conditions need to be fulfilled for the church to provide meaningful guidance? I substantiate my answers to these questions by drawing on the findings of published Christian ethical and social scientific research.

Before addressing these questions, I want to add that for the purposes of this article, I understand the concept of 'church' inclusively. With 'church', I do not only refer to church denominations but

Note: Special collection entitled Christian Leadership, sub-edited by Wessel Bentley (UNISA). 
also to theological institutions, ecumenical organisations, local congregations, voluntary Christian societies and individual Christians (cf. De Villiers 2013:96-97). I have in the article, for the most part, the global church in these six manifestations in mind but do occasionally also touch on the South African church and the specific situation in which it finds itself today.

\section{Does the church have a responsibility to provide guidance?}

A negative answer to this question comes from quite different quarters.

Harari himself belongs to those secular sceptics who do not see any constructive role for the church to play with regard to the solution of global problems. From what he writes in his book, it is clear that he is one of those academics who believe that modernisation has resulted in the irreversible differentiation of autonomous social orders such as politics, the economy, science and technology, in which traditional moral values do not have a role to play anymore (for a discussion of social differentiation, see De Villiers 2018b:165-173). For him, the only relevant problems that need to be addressed in solving global challenges are technical and policy problems, to be tackled by purely functional means of a political, economic, scientific and technological nature. He nowhere acknowledges the fact that ethical considerations should also be taken into account while solving these problems. With that, he takes sides with political realists, neo-liberal capitalists and technicists who are convinced that the momentous global challenges of our time could be solved in a purely functionalist manner (cf. De Villiers 2018b:187-189).

The Achilles heel in Harari's argument (see Harari 2018:127138 ) is that he completely ignored the widespread realisation, especially after the Second World War, that reliance on purely functionalist considerations often does not contribute to the solution of global problems but rather tends to aggravate them. This has led to a new appreciation of the indispensable role of moral values in providing normative frameworks within which political, economic and technological activities have to be channelled. Two examples can be stated in support. The Nazis' political goal of the racial purification of the German nation at all costs led to the extermination of $6 \mathrm{~m}$ Jews during the Second World War. In response, the United Nations, in 1948, ratified the Universal Declaration of Human Rights, based on the recognition of the equal dignity of all human beings, as a moral and legal instrument to guide politics and to prevent the repetition of such atrocities in the future. Contrary to expectations, economic globalisation, fuelled by neoliberal capitalism and rapid technological development, has not brought about worldwide prosperity but has resulted in the enrichment of a minority and the impoverishment of many, as well as the intensification of ecological devastation. As a result, there is today widespread recognition that age-old moral principles such as justice and moderation need to guide economic and technological activities.
Should we recognise that moral considerations play an indispensable role in solving global problems, the Christian religion - and other religions - cannot be so easily left out of the equation as Harari wants us to believe. After all, the Christian church has made major contributions to our contemporary understanding of moral notions such as the equal dignity of all human beings, justice and moderation.

There are, however, not only secular sceptics who question the responsibility of the church to contribute to the solution of global problems but also religious sceptics within the church itself. Firstly, there are those Christians who believe that to expect the church to become involved in solving global problems is to tempt it to divert from its true mission, namely, to devote itself to the proclamation of the gospel of the salvation from sin and eternal damnation through the death and resurrection of Jesus Christ. They take it for granted that the new life in Christ entails being actively involved in typically religious activities such as attendance of church services, bible study, prayer and witness to non-believers.

Secondly, there are also those Christians, who, like Stanley Hauerwas, accept the fact that Christian life entails more than involvement in only religious activities. They are convinced that disciples of Christ should also, like Christ, live a life of moral righteousness and selflessly serve their fellow human beings (for Hauerwas's view on discipleship, see Hauerwas 1981:83-85, 2001:523). Discipleship, however, does not in Hauerwas' view include the responsibility to join initiatives to promote social justice in public life in liberal societies such as the United States. The reason is that as a result of the separation of state and religion in liberal societies, conceptions of justice peculiar to particular religions are not allowed to influence public life. Only the liberal conception of justice, which is regarded as universally valid, is accepted in the public sphere. However, a church promoting social justice in a liberal sense of the word does not serve the cause of Christ, but the cause of political liberalism (Hauerwas 1991:45-68). Instead of undertaking all sorts of social ethical initiatives in public life, the church should rather, in Hauerwas's (1997; for a critical discussion of Hauerwas's view, see De Villiers 2003:24-26) view, serve as a model of how a true community should look like:

The task of the church [is] to pioneer those institutions and practices that the wider society has not learned as forms of justice ...The church, therefore, must act as paradigmatic community in the hope of providing some indication of what the world can be, but is not ...The church does not have, but rather is a social ethic. (pp. 142-143, 24-26)

The problem with restricting the Christian responsibility of the church to religious activities, or activities relating to moral formation and service to fellow human beings, and denying that it also relates to transformational activities aiming at more just and peaceful world, is that the Biblical message of the Kingdom of God points in another direction. Already in the creation stories of Genesis, God's care for the whole of his creation, and the comprehensive responsibility he bestows on human beings to look after his creation as his 
stewards are proclaimed. In the prophetic books of the Old Testament, the vision of the coming peaceable Kingdom of God is central. Peace or 'shalom' in the Old Testament does not only refer to the absence of violence or war, nor only to inner peace and peace with God, but also to the prevalence of justice and harmony, of comprehensive well-being, in society at large (cf. Is 32:1; Ps 72:3). 'Shalom' also comprises harmony between human beings and nature, and harmony within nature itself (Is 11:6-9). The coming peaceable Kingdom of God is thus understood as a Kingdom in which the reign of God goes hand in hand with comprehensive and multidimensional peace (for the reference to 'shalom' in the Old Testament see Dietrich 1987:134-161).

It is the message of the New Testament that the peaceable Kingdom of God has broken into this world in the person and actions of Jesus Christ (cf. Lk 2:14; Mt 4:17; Eph 2:14, 17). Through his death on the cross and his resurrection, he brought about reconciliation between God and human beings, broke the power of sin and opened up the possibility of a new, righteous and peaceful life. As with this reconciliation, the main cause of comprehensive disruption in the world, namely sin, has lost its domination; Paul does not shy away from saying that 'God was in Christ reconciling the world with himself' (2 Cor 5:19).

Just as important, however, is the message of the Bible that we as Christians are called to witness God's reign of a comprehensive peace that broke into this world in the life and death of Christ. Paul stresses in 2 Corinthians 5 that God 'has enlisted us in [the] service of reconciliation', has 'entrusted us with the message of reconciliation' (2 Cor 5: 19-20). Christians have the responsibility to, through word and deed, live out this reconciliation in all the relationships in which they are involved. They have the responsibility as the church to be an alternative community that demonstrates to the world what the new life in Christ entails. But, they also have the responsibility, in the workplace and in society, and when they have the opportunity to do so even in the wider world, to strive to heal broken relationships, restore moral standards, combat human need, overcome injustice and care for the natural environment.

One can also put it this way: although the coming of God's kingdom entails more than the flourishing of living beings, it is certainly part of what God intended. The words of Jesus in John 10:10: 'I have come that they may have life, and have it to the full', among others, provide a concise formulation of the intent of the coming of God's Kingdom that commenced in his own life and ministry. These words more specifically refer to the flourishing of human beings. In light of the full Biblical message on the Kingdom of God, one could, however, assert that God wishes the flourishing of living beings on earth and also expects Christians to support initiatives that contribute to it (cf. De Villiers 2018a:8). As this wish of God also applies to living beings in the future, we have a corresponding responsibility to now do what we can to contribute to the flourishing of living beings in the future.

\section{What is the nature of the church's guidance?}

How should the church fulfil its comprehensive stewardship responsibility when it comes to global problems? From what has been said so far, it is clear that the advice it can offer does not pertain to technical and policy means in solving such problems but rather to the moral guidance it could provide.

It is important to distinguish between two levels of moral guidance with regard to the solution of global problems the church could offer. The first is the intra-church level of moral guidance to denominations, congregations, Christian nongovernmental organisations and individual Christians. The second is the extra-church level of moral guidance to the public, companies, national and international agencies, and governments.

When it comes to intra-church moral guidance, the church can draw not only on the Bible as a source but also on the 2000-year-old tradition of theological reflection and church proclamation on moral issues relating to inter alia war, poverty, injustice, the protection of the natural environment and a moderate lifestyle. The church should, of course, be careful to not directly apply Biblical guidelines to modern problems of which the authors of the Bible did not and could not have any knowledge. Explication and interpretation of relevant Biblical material could, however, play an important motivational role in making members of the church aware of the responsibility they also have with regard to the global problems we face today and in inspiring them to contribute to their solution. It could also provide moral orientation on present-day global problems by stirring the imagination in finding new and original avenues in tackling these problems. The Old Testament message on the creation of all human beings in the image of God, God's appointment of human beings as stewards of his creation, the comprehensive peace that characterises God's Kingdom and justice entailing special care for the poor and the needy comes to mind. The same is true of the love commandment in the New Testament and the radical message of the Sermon on the Mount on reconciling with someone who has a grudge against you, breaking the vicious circle of retaliation, loving the enemy, not making money a priority, not being anxious about material needs and not judging others but admitting your own shortcomings. Normative analogies could even be drawn between the church's new life in Christ as sketched in the New Testament (such as the realisation of visible unity, joining natural and cultural differences into life-giving richness, and real reconciliation, overcoming deep divisions and structures of alienation) and the new national and global societies we should strive for in overcoming the deep racial, gender, cultural, class and national divisions we experience today (Smit 2002:8; cf. De Villiers 2017:139).

Apart from explicating Biblical material, the church could invite experts to inform members on pressing national and global problems and stimulate discussion on such issues 
among them. It could also initiate projects, which on a small scale contribute to the solution of a pressing national or global problem, such as assisting poor people to start a vegetable garden, crossing racial and class borders by maintaining active partnerships with congregations and welfare organisations operating in poor and segregated neighbourhoods, organising cleaning up operations in polluted areas and providing containers at the church for recyclable refuse and encouraging members to make use of them. The value of such projects lies not only in the fact that they provide models that could on a larger scale be emulated by church members in different contexts but also in cultivating, in especially the youth, the virtues and skills needed to successfully tackle such problems.

When it comes to extra-church moral guidance regarding the solution of global problems, the church is faced with a different situation. It has to take into account the fact that different social domains, such as politics, the economy, science and technology, because of modernisation, freed themselves from the control of traditional religious and moral values and operate in accordance with their own autonomous sets of functional and non-religious moral values. One of the results of this differentiation of different social orders with their own set of values is that in liberal democracies, the principle of the separation of state and religion is recognised, which means that the state may not favour any particular religion or base any legislation on religious beliefs.

What are the implications of this development for the extrachurch moral guidance on global issues the church could provide? We have already seen that people like Stanley Hauerwas regard the predominance of secular values in liberal democracies as an insurmountable stumbling block for any effort by the church to exert a public influence regarding social justice issues. The Dutch theologian Gerrit de Kruijf has a different view. He does come to the conclusion that the Barthian approach of explicitly Christian prophetic witness in public on political and economic matters is not appropriate and, in any case, fruitless in contemporary liberal democracies (De Kruijf 1994:40-52, 236-240). Should Christians want to responsibly contribute in such societies to policy formation, they, in his opinion, should not make pronouncements on societal issues on the basis of their own 'thick' or strong Christian morality but should do so rather on the basis of the 'thin' cultural values shared by all in plural societies (De Kruijf 1994:194-195). ${ }^{1}$

In response to the views of both Hauerwas and De Kruijf, I would like to say that much depends on the society the church finds itself in. In liberal democracies like France and the United States, which are characterised by a 'hard' or strict separation of state and religion and where the liberal prejudice against introducing religious views in the public

1.The social scientist Peter Beyer has a rather similar view in this regard. He is of the opinion that the predominance of globalisation as the contemporary outcome of opinion that the predominance of globalisation as the contemporary outcome of the process of modernisation does not necessarily mean that the public role of religion has been played out. It can still play an important role in strengthening public protest against political and economic aberrations. It should then, however, take its point of departure in liberal moral values like equality and freedom, as is th case in liberal Christianity (e.g. the WCC) (Beyer 2001:273). sphere is strong, expressing Christian moral views on national and global issues in public would mostly be counterproductive. In democracies like South Africa where the constitution demands a 'soft' or more lenient separation of state and religion, the media often carry discussions on religious matters, and the majority of the population are Christian and understand Christian language, there is still considerable room for expressing Christian views on, among others, global problems in public. Such discussions could even contribute to shifts in public opinion on such problems.

De Kruijf, however, is in my opinion right in saying that Christians could hardly expect legislation in liberal democracies to be based on strong Christian values. Legislation - for example, on abortion - has to allow different-minded groups and individuals to act in accordance with their own consciences. And the same is true in most workplaces. Christian employees cannot expect their company or government departments, which employ people from different creeds and cultures, to be run in accordance with Christian moral values. In such situations, they have to base their arguments in favour of certain policies or actions, for example, to counter global warming, on shared moral values subscribed to by people from different religious and cultural backgrounds.

What do we then make of Hauerwas's objection that Christians, when they subscribe to shared moral values, do not promote the Christian cause, but the cause of liberalism? First of all, I want to respond that it is not true that the shared moral values to which Christians have to relate their arguments are always liberal in nature. In social domains like the economy, science, healthcare and technology and the professions and organisations that operate within them, shared moral values, often expressed in professional and organisational codes, differ from profession to profession and from organisation to organisation and change over time. The moral consensus with which Christians have to work in such cases is always social-context-specific. The same applies to politics. Even different democracies are not always based on exactly the same shared moral values. Differences in the number and mix of human rights that are recognised in the constitutions of different democracies attest to that.

More importantly, I have a problem with Hauerwas's view that the actions of Christians should always be based on distinctively Christian moral notions. I would rather agree with Nigel Biggar when he stresses that '[i]ntegrity, not distinctiveness is the point' (Biggar 2011:9). The reason why one should not overstress distinctiveness is that it is, for the most part, an accident of history. To quote Bigger, 'whether or not what the Christian ethicist has to say is distinctive is dependent on the happenstance of whom he is talking with and what he is talking about' (Biggar 2011:8). Far more important than whether Christians in particular circumstances base their arguments on distinctively Christian moral notions or rather on shared moral notions is whether doing so enables them to promote a cause that is commensurate with their basic Christian moral beliefs. 
This conclusion regarding the priority that the integrity of Christian moral notions has over their distinctiveness is of extreme importance when it comes to the moral guidance the church could provide outside its own sphere. The church can in its own sphere take a moral stance on global issues that motivate and guide its own members and can initiate projects that on a small scale contribute to the solution of such issues. However, it remains true that the scale of global problems is of such magnitude that world-wide cooperation and coordination is needed in order to be of significance. Yuval Harari is right: global problems need global answers (Harari 2018:111). Should the church wish to effectively contribute to the solution of these problems, it just has to find common moral ground with other role-players and accordingly work with them. It has to do so because only by doing so can it fulfil its responsibility towards promoting the protection and flourishing of all life in God's creation.

\section{Which factors hinder the church in providing guidance?}

It is an undeniable reality that in many churches worldwide, very little, if anything, is seen of this twofold moral guidance the church can provide regarding global problems. Why is this the case? I would like to briefly highlight some of the main hindrances for providing this moral guidance.

\section{Ideological hindrances}

Yuval Harari is of the opinion that the grip nationalist ideologies today have on religions render them incapable of providing any meaningful guidance with regard to global problems. One can rightfully object that he overly generalises and that many examples can be given of Christian churches not serving nationalist interests. This does not take away from the fact that many churches in the past fell for the temptation of supporting nationalist ideologies; the Afrikaans churches in South Africa during the apartheid era and the Deutsche Christen in Germany during the reign of national socialism, being two blatant examples from the recent past. In the United States, Donald Trump can today count on the fervent support of many evangelical churches and their members for his clearly nationalist ideology of 'America first', which threatens to undermine world peace. $^{2}$

\section{Doctrinal hindrances}

I have already mentioned certain doctrinal views on salvation and the mission of the church that do not recognise the responsibility of the church to contribute to the solution of global problems. In especially the Reformed tradition, the responsibility of the church to also contribute to the holistic transformation of society has been recognised from the start.

2.John de Gruchy points out the tendency in many African states in the post ence period for ruling elites belonging to one dominant ethnic group, to form informal their own privileged status. 'This often led to the co-option of the churches as uncritical servants of the state, giving legitimacy to policies which were morally suspect, socially disastrous, and counter-productive to Christian witness' (De Gruchy 1995:170)
The goal of this transformational responsibility of the church has, however, been mostly understood as 'christianising' the society. A completely christianised society is one in which the Lordship of Christ is explicitly recognised and the moral guidelines of the Bible are regarded as the final measure for policy formation in all spheres of life

As we have already noticed, this exclusively Christian approach to the transformation of society, whether national or global, has lost its legitimacy in modernity. This leaves many churches, also in South Africa, in great uncertainty about the appropriate way to respond to public issues.

A still influential view of God's providential rule in this world is one in which a sharp distinction is made between God's actions in this world and our own human actions. To truly believe in God's providence, according to this view, is to wholly rely on his intervention, and not on human initiative. An extreme example is that of those Christian groups that do not vaccinate their children against measles or polio, because it, according to them, implies a lack of faith in God's providence. ${ }^{3}$ One of the implications of this understanding of God's providence is that for the church to take co-responsibility for the solution of global problems is to arrogantly deny our total dependence on God for determining the future of humankind.

\section{Hindrances relating to church-centredness}

Many factors contribute to church-centredness. One factor is fear of losing one's distinctively Christian identity. We have already taken note of Hauerwas's view that the church jeopardises its distinctive Christian identity by becoming involved in public issues in liberal democracies.

Another important contemporary factor is the struggle for institutional survival. Many denominations and congregations all over the world, but especially in Europe, have over the last century experienced a serious loss in membership numbers and income as a result of secularisation (see Joas 2012:34-36; Taylor 2007:513-514). To a lesser extent, South African churches have also experienced this, especially after the introduction of the new democratic dispensation in 1994. The introduction of this new political dispensation finally broke down the cultural isolation during the previous political dispensation and also opened the flood doors for secularising influences. The loss of membership numbers and income often leads to a survival-mode and the pre-occupation with projects that could secure the institutional survival of one's own denomination or congregation.

A related factor is a need for personal and social security. Especially in a social environment that is experienced as threatening their personal security and the security of their family or cultural group, people turn to their church denomination or their congregation in the hope that it will

3.In the eighties of the previous century, a well-publicised case in point was the refusal of conservative Reformed Christians in the Dutch town of Staphorst who on similar grounds refused to inoculate their children against polio. 
provide a 'safe haven'. ${ }^{4}$ The security they seek from the church is not so much of a physical nature but of an emotional and spiritual nature. They expect the pastor to comfort them, ensure them of God's continued protection and, at least for the duration of the sermon, help them to totally forget about the unpleasant reality outside the doors of the church. What they definitely do not want the pastor to do is to remind them of their responsibility to constructively contribute to the solution of societal and global problems.

\section{Hindrances relating to pluralisation}

Especially after the Second World War, modernisation processes have had a strong individuating effect in the Western world, meaning that individuals have increasingly adopted their own distinctive lifestyles and sets of beliefs, including moral beliefs. Charles Taylor in his monumental study on secularisation with the title $A$ secular age referred to the 'individuating revolution' experienced in contemporary Western culture during the last 70 years or so (Taylor 2007:473). Among others, the result has been a dramatic increase in the plurality of moral views held by Christians, even among those who are members of the same church. During especially the last two decades, the pluralising impact of modernisation on the moral stances of Christians could also be clearly detected in South Africa. It is not only the case that a whole spectrum of views can today be found among Christians on 'big' ethical issues like same-sex relationships, abortion, euthanasia, capital punishment, climate change, the use of nuclear energy and fossil fuels, the impact of social media and animal rights but also that they differ quite significantly on what an appropriate personal Christian lifestyle entails.

This, of course, creates challenges for churches. It is difficult to meaningfully preach on ethical matters without annoying at least some members. The temptation is, therefore, to avoid preaching on such matters, or to do so in such a vague or abstract manner that very little ethical orientation is provided. It is also difficult to take a clear common moral stance on important social and global issues or to undertake joint projects based on moral concerns as the necessary moral consensus is lacking.

\section{Hindrances related to fundamentalism}

Fundamentalism refers to an aggressive way of responding to the threats modernisation poses for religion. The term 'fundamentalism' was coined to identify a counter-movement against theological liberalism and cultural modernism initiated among conservative Protestants in the United States and Great Britain in the late 19th and early 20th century. This counter-movement strongly defended the inerrancy of the Bible and orthodox Christian doctrines. Today, it is more generally used to refer to the radical defence of religious convictions against the undermining effect of modernisation.

4.Jürgen Moltmann uses the term 'inward emigration' to describe the tendency of church members to avoid engagement with the problems of society and seek solace in the church as a safe haven (Moltmann 1974:37-41).
Part of most fundamentalism is the resolute insistence that a particular version of religion is absolutely true. The flip side of this approach is that other versions of the same religion and other religions are often condemned as absolutely false. It goes without saying that churches with fundamentalist sentiments would not be willing to work together with other churches and religious groups to find moral consensus regarding the solution of global problems.

\section{Which conditions need to be fulfilled?}

The church would only be able to provide adequate moral guidance regarding the solution of global problems when it succeeds in overcoming the above-mentioned hindrances. The conditions that need to be fulfilled are discussed in the following text.

\section{Introducing doctrinal reform}

When certain doctrinal beliefs are out of tune with the existing social reality or undermine the responsibility of the church to provide moral guidance on societal problems, an option to reform these doctrines should be considered. Such a proposal may sound radical, but was the fact that fundamental changes had taken place in society in the past not often one of the reasons for doctrinal reform in the church? Martin Luther in proposing drastic doctrinal reform during the Reformation responded to malpractices and doctrinal distortions in the church, and also to changes in society: the emergence of a middle class of predominantly merchants who cherished their independence from authoritarian powers and a new sense of appreciation of the initiative and dignity of the individual since the start of the Renaissance. ${ }^{5}$ Luther, like most church reformers, did not fabricate his proposals of doctrinal reform all by himself but discovered, retrieved and interpreted neglected insights from especially the Biblical tradition that would be applicable in the circumstances of his own time. In the same way, we should retrieve and interpret insights from the Christian tradition that would help us alter doctrinal beliefs that prevent the church in optimally fulfilling its comprehensive mission in the world.

I already mentioned the need to bring doctrinal beliefs about the purely spiritual nature of salvation in Christ and the mission of the church more in line with what the Bible teaches about the comprehensive and inclusive Kingdom of God and the comprehensive mission of the church that goes hand in hand with it. But what should we do with regard to the doctrinal belief, central especially to Reformed confessions, that the church should strive to attain the full Christianisation of every aspect of society? This belief has not only become highly problematic in contemporary societies characterised by the differentiation of social orders, including the separation

5. For the role of the emergence of a class of merchants, an anti-monarchal attitude and the emphasis on the individual played in the Renaissance see Skinner (1979:69), and the emphasis on the individual played in the Renaissance see Skinner (1979:69),
and for the relation between the humanism of the Renaissance and the Reformation see Koopman (1962:38-41). 
of state and religion, but has also become almost impossible to realise in such societies. Should the conclusion drawn earlier in the article from the biblical message on the Kingdom of God that God wishes the flourishing of living beings on earth and also expect Christians to support initiatives that contribute to it be correct, there is no reason to persist on the fact that Christianisation is the goal of the transformational task of the church regarding society. This goal could and, in my opinion, should be supplanted with that of the flourishing of living beings on earth. This opens the possibility for the church to cooperate with and contribute to all initiatives, even those of non-Christians, that enhance the optimal flourishing of living beings on earth.

There is also no need to accept the doctrinal belief that trust in God's providence in future excludes all initiative from our side. This doctrinal belief does not only fly in the face of the growing contemporary awareness that we humans are, to a large extent, responsible for the dire condition of the world, and should take full responsibility for improving it, but also contradicts what the Bible teaches about the work of the Holy Spirit. Paul, after exhorting the Philippians to maintain a life of obedience to God, adds these extraordinary words: 'you must work out your salvation in fear and trembling; for it is God who works in you, inspiring both the will and the deed, for his own chosen purpose' (Phlp 2:12-13). These words of Paul in a striking manner sum up what the New Testament teaches about the work of the Holy Spirit: he guides us not only in a hidden way working in and at us but also with us in the sense of together with us. It is typical of the work of the Holy Spirit that what he works in us is always carried out as our own work. Thus, as Christians, we can and should take full responsibility to contribute to the salvation of our world, while at the same time acknowledging that we have to give full credit to the Holy Spirit for guiding and enabling us to do so. ${ }^{6}$

\section{Resisting church-centredness}

The church would only be able to provide moral guidance with regard to a global problem to the extent that it succeeds in adequately resisting factors contributing to churchcentredness.

With regard to the contributing factor of an institutional survival mode, I want to point out that the church should avoid regarding the process of secularisation as an unstoppable one, which will inevitably lead to the total demise of all religions, including the Christianity. Although both Europe and the United States have experienced extreme modernisation, the churches in the United States have not been affected so much by secularisation as the churches in Europe. In fact, in the period from 1800 to 1950, during which the membership of the European churches steadily declined,

6.The Dutch theologian AA van Ruler in this regard makes a distinction between Christoli the redegy the redemptive work of Christ as a substitution for hum an initiative, it is not the case when it comes to the work of the Holy Spirit. It would be more appropriate to use the term 'theonomic reciprocity' than 'substitution' to describe the work of th Holy Spirit (Van Ruler 1964:205-227; cf. De Villiers 1978:172-174). membership of churches in the United States grew steadily. To some extent, this can be ascribed to the influx of immigrants; yet, according to social scientists, it should be ascribed in the first instance to the early separation of church and state, which encouraged freedom of religion and contributed to a vibrant and variegated religious life (Joas 2012:36-39; cf. also De Villiers 2018b:157-165). Totally avoiding political interference in its internal matters and effectively catering for the growing variety of doctrinal and moral beliefs and spiritual needs of members are two ways in which a denomination could retain member interest and loyalty.

With regard to the tendency of members to expect their congregation or denomination to be a safe haven, I want to remark that pastors and church leaders should not as a result of this expectation fall for the temptation to suffice with priestly comforting. They should also equip their members to, in the midst of difficult circumstances in the workplace and the wider society, fulfil their kingly office by setting an example of what it means to live a morally upright life, as well as their prophetic office of providing moral guidance and constructive criticism with regard to global problems. Should churches succeed in doing this, chances are that not only their members but also people who are alienated from the church would recognise the comprehensive relevancy of the Christian message and be attracted to the church.

\section{Overcoming the negative effects of pluralisation}

No effective initiative contributing to the solution of a particular global problem could be undertaken without adequate agreement among participants on the moral norms guiding the initiative. The same is true for the church. To overcome the negative effects of pluralisation in its midst, the church should realise the need to first reach adequate moral agreement when it considers undertaking projects. The search for moral agreement could only succeed when all roleplayers are in one way or another involved, have the opportunity to make inputs and buy into final agreements. To be realistic, in many denominations and congregations, it would often not be possible to reach adequate moral agreement among all the role-players. Why not then allow those members in the church who feel strongly about undertaking a particular project to initiate it and recruit other members in the denomination or congregation, sharing their moral convictions, to participate? And, should a church project not come from the ground, why not encourage church members to join action groups and societies outside the church promoting a cause they support?

\section{Overcoming fundamentalism}

Seeking moral agreement and cooperating with fellowChristians and non-Christians who do not fully agree with my moral views presupposes not absolutising my own moral values. To de-absolutise one's own moral views, to not 
regard these views as absolutely true, is one way of overcoming fundamentalism. But does this proposal not undermine the convictional certainty that goes hand in hand with religious belief? It is undoubtedly true that religious convictions, whether moral or not, require unconditional commitment from believers. Having convictional certainty on a particular ethical view does, however, not imply the epistemological certainty, in the sense of epistemological infallibility, of this view. Even Christians should be open to criticism of their moral views and be willing to change or adapt them when they do not stand up to criticism.

Another implication is that Christians ought to be much more tolerant or hospitable ${ }^{7}$ - to use a concept from the Christian tradition - over against fellow-Christians and nonChristians who have views on ethical issues that differ from their own. This tolerance or hospitality should not be misunderstood as indifference but rather be based on the acknowledgement that we are all truth-seekers who only have limited access to the truth and constantly need to test our own moral views against the arguments of those who differ from us. Christians should, therefore, be motivated to actively engage in constructive critical discussions with those having different views in the hope of reaching a stronger moral agreement.

\section{Resisting ideological allegiances}

The church should constantly be vigilant against the disruptive influences of ideological allegiances in its midst. The identification with the interests and views of one's own political party, cultural group, class or gender has a way of inadvertently colouring one's moral views on, among others, global problems. A denomination or congregation whose members largely belong to a certain political party, cultural group or class would be especially prone to support moral views that serve the interests of their own group. Against this temptation, the church should uncompromisingly adhere to and proclaim to their members the message that they owe their highest allegiance to Christ and should at all times maintain the inclusiveness and impartiality of Christian morality.

\section{Conclusion}

I have in this article addressed the question, 'does the Christian church have any guidance to offer in solving the global problems we are faced with today?' The conclusion is: the question can be answered in the affirmative in as far as the church has meaningful moral guidance to offer. The church should then, however, depart from an unbiased understanding of the message of the Bible and effectively deal with the hindrances preventing it from providing adequate moral guidance. The proposals made in this article are unavoidably of a general nature. The difficult challenge remains of working out how the church could provide

7.For a discussion on hospitality as a Christian virtue, see Smith and Carvill $(2000$ 79-103). concrete moral guidance with regard to the solution of each of these global problems.

\section{Acknowledgements Competing interests}

The author declares that he has no financial or personal relationships that may have inappropriately influenced him in writing this article.

\section{Author's contributions}

D.E.d.V. is the sole author of this research article.

\section{Ethical considerations}

This article followed all ethical standards for a research without direct contact with human or animal subjects.

\section{Funding information}

This research received no specific grant from any funding agency in the public, commercial or not-for-profit sectors.

\section{Data availability statement}

Data sharing is not applicable to this article as no new data were created or analysed during this study.

\section{Disclaimer}

The views and opinions expressed in this article are those of the author and do not necessarily reflect the official policy or position of any affiliated agency of the author.

\section{References}

Beyer, P., 2001, 'The global environment as a religious issue: A sociological analysis', in D. Herbert (ed.), Religion and social transformations, pp. 261-312, Ashgate, Aldershot.

Biggar, N., 2011, Behaving in public: How to do Christian ethics, William B. Eerdmans Publishing Company, Grand Rapids, MI.

De Gruchy, J.W., 1995, Christianity and democracy: A theology for a just world order, David Philip, Cape Town.

De Kruijf, G.C., 1994, Waakzaam en nuchter: Over Christelijke ethiek in een democratie, Ten Have, Baarn.

De Villiers, E., 1978, Die eiesoortigheid van die Christelike moraal, Rodopi, Amsterdam.

De Villiers, E., 2003, 'A Christian ethics of responsibility: Does it provide an adequate theoretical framework for dealing with issues of public morality?', Scriptura 82(1), 23-38. https://doi.org/10.7833/82-0-895

De Villiers, E., 2013, 'Public theology in the South African context', Journal of Theology and Religion in Africa 37(1), 83-107.

De Villiers, E., 2017, 'The vocation of the reformed ethicist in the present South African society', in C. Pearson (ed.), Imagining a way: Exploring reformed practical theology and ethics, pp. 145-160, Westminster John Knox Press, Louisville, KY.

De Villiers, E., 2018a, 'Christian ethics and secularisation: Business as usual?', Verbum et Ecclesia 39(1), a1796. https://doi.org/10.4102/ve.v39i1.1796

De Villiers, E., 2018b, Revisiting Max Weber's ethic of responsibility, Mohr Siebeck, Tübingen.

Dietrich, W., 1987, 'Ungesicherte Friede? Das Ringen um ein neues Sicherheitsdenken im Alten Testament', ZEE 1987(2), 134-161.

Harari, Y.N., 2018, 21 Lessons for the 21st century, Jonathan Cape, London.

Hauerwas, S., 1977, Truthfulness and tragedy: Further investigations in Christian ethics, University of Notre Dame Press, Notre Dame.

Hauerwas, S., 1981, Community of character: Toward a constructive Christian social ethic, University of Notre Dame Press, Notre Dame.

Hauerwas, S., 1991, After Christendom? How the church is to behave if freedom, justice, and a Christian nation are bad ideas, Abingdon Press, Nashville, TN. 
Hauerwas, S., 2001. The Hauerwas reader, in J. Berkman \& M. Cartwright (eds.), Duke University Press, Durham, NC.

Joas, H., 2012, Glaube als Option: Zukunfsmöglichkeiten des Christentums, Herder, Freiburg.

Koopman, W.J., 1962, Luther: Zijn weg en werk, W. Ten Have, Amsterdam.

Moltmann, J., 1974, Man: Christian anthropology in the conflicts of the present S.P.C.K., London.

Skinner, Q., 1978, The foundations of modern political thought, vol. 1: The renaissance, Cambridge University Press, Cambridge.
Smit, D.J., 2002, 'Comments and questions', Unpublished presentation on a research project under the auspices of the Center of Theological Inquiry, Princeton, NJ.

Smith, D.A. \& Carvill, B., 2000, The gift of the stranger: Faith, hospitality and foreign language learning, William B. Eerdmans Publishing Company, Grand Rapids, MI.

Taylor, C., 2007, A secular age, The Belknap Press of Harvard University Press, Cambridge, MA.

Van Ruler, A.A., 1964, 'Structuurverschillen tussen het christologie en het pneumatologische gezichtspunt', in J. De Graaff (red.), De Spiritu Sancto: Bijdragen tot de leer van die Heilige Gees bij gelegenheid van het $2 e$ eeuwfeest van het Stipendium Bernardinum, pp. 205-227, Kemink, Utrecht. 